\title{
Study on the Spirit of Oriental Culture in the New Art Movement
}

\author{
Chong Lan \\ Lanzhou Jiaotong University \\ Lanzhou, China 730070
}

\begin{abstract}
At the end of 19th century, the oriental trend has become fashionable for a time in the circle of western art. It has profoundly influenced the new art movement in painting, architecture, interior design, furniture, book decoration etc., which were very popular in design and art circles at the beginning of 20th century. In this paper, the author combs and analyzes the new art movement under the background of the integration of the western-and-eastern culture, and focuses on the oriental spirit in the new art movement in order to reveal the precious spirit of cultural exchange and innovation in the new art movement.
\end{abstract}

Keywords-the new art movement; the oriental art; architectural design; book decoration

\section{INTRODUCTION}

Every art and design style is the reflection of social politics, economics, culture and psychology. At the end of nineteenth century, western countries completed industrial revolution, European economy flowers as never before, and people began to review the life and themselves, reflect life opinions formed through hundreds and thousands years, and criticize social vulgarity and corruption as well as reform the manufactures in a rough way and pursue a new life. As a result, innovation becomes popular at that time. People's affection for new things, and their attention on and desire for new life lead to the appearance of new art movement. Originated from England but having great influence on foreigner countries, new art movement spread to Europe and America through France and Belgium, and shows very complex: being called "young styles" in German, "Vienna Secession" in Austria, "new art" in France and Belgium. Although art styles are totally different, they have common basis, which are pursuing the selfdiscipline of art, hoping to explore and create new art contexts and languages by using group powers, and showing the characteristics of life and the time in new forms.

\section{THE NEW ART MOVEMENT}

The New Art (Art Nouveau) mainly refers to a decorative art style which has been widely popular in the Europe and the United States from the late 19th century to early 20th century. Art Nouveau originally was the name of a gallery in Paris. Later it is referred to as "New Art". According to the academic history, from the end of the 19th Century to the First World

Fund Project: the Research Project of the Youth Science Foundation of Lanzhou Jiaotong University (2014060)
War, all the avant-garde, progressive and experimental art activities in Europe and America were all called as "Art Nouveau". It involves a wide range of areas, and nearly includes all categories of art and design, such as painting, architecture, interior decoration, furniture, book illustration design, glassware design, jewelry design and poster design. A lot of areas and regions were influenced by this movement, including France, Belgium and Austria in Europe, the United States and even Japan and China in Asia and other countries, so it is an international movement with a huge influence in the history of art and design.

"Art Nouveau" has made a great achievement in the history of art. It mainly lies in that the representative artists of the new art movement abandoned the mainstream and official, longdominating classic imitating form in the art circle in Europe and America, and extensively drew from the exotic art style of the Orient and the ethnic minorities. These artists got inspiration from the nature, imitated all free and curve forms of plants in the nature, and created and established a pleasing style of art which is obviously distinctive from the classic style. Its main characteristic of the style is an extensive use of winding and slender natural curves as basic element to express things of the nature, so their works have a strong sense of frame, and they give people a sense of flow, rhythm and grace.

\section{THE INFLUENCE OF THE ORIENTAL CULTURE ON THE NEW ART MOVEMENT}

The artists of Art Nouveau attached great importance to drawing upon the traditional art form of the European and foreign artistic styles, such as Celtic and Saxon jewelry and illustrations, and Japanese painting and decorative art and Chinese traditional painting art from Asia. The Japanese art form adopts the specific scatter plot of the oriental art, which obviously doesn't conform to the scientific spirit of the Europeans in perspective. But it is the specific composition form, the use of bright subjective colors and unique and wonderful lines that draw the eyes of the European and American artists on Japanese art, which has become one of main driving factors in the reform of the western art. For example, European artists have learned to design a twodimensional plane space, reduce and weaken the perspective effect and balance the relationship of line and color from Japanese artist Katsushika Hokusai, Ando Hiroshige and Utamaro. Therefore, in the study of art history, some European scholars believe the oriental art, especially Japanese art, is the 
cradle of western modern art pioneer impressionism, and its significance is as important as the that of renaissance.

It was the exotic oriental art that touched the soul of European artists who resolutely abandoned the traditional classic imitating style in the creation and embraced the arms of the nature like the impressionism artists to feel the beauty of the nature and get inspiration. They found various beautiful different curve elements in the nature and asymmetric forms different from traditional symmetric forms which are the rules of new formal beauty. Based on this, they widely used plant petals, leaves, stems, veins and other basic elements to purely show the style of the nature. The evolution of any art history needs artists to have the ability of independent observation and thinking and creative spirit. The artists of new art movement have such ability and spirit, where it is commendable. The artists of the new art movement had open mind and learnt new knowledge inclusively, and drew essence from the beauty of nature in the integration of eastern and western art. Based on the study and practice of the oriental art forms, they got inspiration from the nature and created. Finally, the new art movement has become an influential art movement in Europe and even the world.

\section{A. The Spirit of Oriental Culture in French Art Nouveau}

Samuel Bing, representative of French Art Nouveau showed special preference to the oriental art, especially Japanese painting art and handcrafts. He had ever been to Japan to experience and purchase Japanese arts and crafts with typical oriental art spirit. In addition, he was also obsessed with Chinese traditional works of art. He had opened a shop in China, called "Home of China" where mainly collected and run art works from China and Japan. He also had published a magazine called "Japanese Arts". In addition to the influence of the oriental art, he was also influenced by Louis Tiffany, representative of American Art Nouveau and famous glass designer. Louis Tiffany advocated the combination of art expression in the production of handicrafts, to achieve the art of life. By this way, the design works of Samuel Bing was full of the innovative spirit and aesthetic artistic style. Like other artists in the new art movement, he got inspiration from the nature, avoid using straight line and geometric patterns in designing works and extensively used natural and organic curve patterns, so that his works have a typical style of art nouveau.

Emile Galle is the representative artist of Nancy Art Nouveau. He has outstanding achievements in furniture design and glass art. He drove the development of new art movement, besides he paid attention to combs theories. He had ever published an important theoretical paper, called "Decorating Modern Furniture According to Nature". In this paper, he systematically described the importance of the thought of naturalism in furniture design. For example, designer should get design inspiration from "natural style, natural form and natural pattern"; the decoration theme should be consistent with the function in product design. Emile Galle put forward the dialectical relationship between "form and function" which has become an important theory in the history of art. In furniture design, he avoided using straight lines geometrical patterns, used natural curves like the oriental art to decorate, and learned the wood mosaic technology from Japanese and Chinese furniture design. His glass arts were famous for various flowers, insects, plant veins and animal patterns. He used his own biological theories to collect these natural patterns, amended and combined them to express his unique artist views.

The famous architect Hector Guimard had made great achievements in architectural design. His master work is the design of Paris's subway entrance which is the representative of new architectural art. It has reflected the peak architectural design level in France. In this work, he blended Rococo art, Japanese art and other art styles together to reach a singular visual effect. For example, use iron technology to express various curves, leaf and stem patterns and seashell patterns in the nature.

Toulouse Lautrec is another special artist in French Art Nouveau. He is also an excellent painter and poster designer. His posters are different from traditional design forms. His works have simple composition, clear contour, strong lines, pure and bright color, and pictures full of oriental art style. At that time, his design has a style of his own in the circle of graphic design.

\section{B. The Spirit of Oriental Culture in British New Art Movement}

Mackintosh, representative of British new art movement is mainly known for architectural design. In his works, he often used various forms of linear combination which is similar to line arrangement in Chinese calligraphy. He learned from Japanese art and created the lattice pattern which is widely used in his works. For example, his mater work "The Hill House" is designed with lattice holes at the front gate, and Japanese lanterns hanging on ceiling in the square hall. His works have a simple, beautiful style, and pay attention to functions, which has a profound impact on current architectural design and interior design.

Beardsley is a genius designer and another representative and pioneer of the British new art movement. His works give huge enlightenment to later new art design, and have a deep influence on the development of art outside Europe. He was fascinated by Chinese folk art when he was young. Later he made further study on Japanese printing art and the vase art of Ancient Greece, and was inspired by these art forms and created two-dimensional decorative art. The natural and beautiful curve forms and black color block create a unique style, which can be content of book illustration and independent art work.

\section{The Spirit of Oriental Culture in American New Art Movement}

The representative of American new art movement and outstanding glass art master Louis Tiffany has a profound understanding on the oriental art, especially how to use various materials with different textures in the works to express the concept and emotion of artists. For example, he used rough pieces of glass in his representative "Bella Apartment". Louis loved to collect art works from China, Japan and the Western Asia, and his works widely use art forms and patterns from 
China, Japan and the Western Asia. His works is dominated by a large number of natural curves with strong decorative implication, and bright and rich colors.

American artist Robert Kushner is good at piecing various patterns from various regions together in order to pursue a striking artistic visual effect in the composition of graphic design. The spiral blooming flowers designed by him shows his rebellion to the over rational creation attitude of current minimalism and conceptual art. He imitated and directly used art forms from the world, such as the Iran Islamic Art, landscape painting and erotic painting of the oriental art, Mexico tile pattern, Moorish architecture, Morocco pottery and Indian's cloth patterns.

The works of American "Architectural Giant" Louis Sullivan were deeply affected by Islamic architectural art. He directly used pavilion of Islamic style, fantastic geometric patterns, gorgeous decoration form and mysterious religious metaphor means of Islamic art, from which he got a lot of creative inspiration. The typical characteristic of the oriental art is the unity of form and meaning which attracted him to use this method. In his representative work "Trust Bank Building", he used a lot of Arabian graphic patterns and complex curve decoration to realize his design concept. The front gate of Chicago Traffic Building "Golden Gate" is designed by him. It is the most beautiful and gorgeous part of the building. Ornate murals, the arch and dazzling color decoration give people a sense of magnificence and grace. The use of plenty of complicated, elegant and exquisite patterns creates a special art effect of oriental embroidery, which greatly responds to the concise form of the building. All of these show that Louis Sullivan has an indissoluble bond with the oriental art, especially Islamic architecture.

\section{The Spirit of Oriental Culture in Belgian New Art Movement}

In Belgium, the representative of the new art movement is Van de Velde. He was a core leader of early design movement. He ever was a professional painter, but turned to architecture in 1890. In 1892 he started working as an industrial designer. He studied extensively and learned from a variety of arts, such as artist Goya's paintings, Japanese Ukiyo-e prints, British art wallpaper. He created a typical Belgian style, which is characterized by a strong sense of movement and a classical beauty of power.

\section{E. The Spirit of Oriental Culture in Austrian New Art Movement}

In Austria the new art movement representative was the famous painter Klimt Gustav. He created a unique style in his works. His works give out the flavor of the oriental art, such as line drawing of Chinese traditional painting, Chinese folk newyear painting with strong color contrast and brocade embroidery patterns of typical ethnic style. As a result, his works show a mysterious symbolic meaning and gorgeous decoration, and flashes brilliant luster, and even comparable to the ancient Byzantine mosaic art.

\section{CONCLUSION}

Under the background of social economic globalization, we have to re-examine the development course of art in a macro perspective, and reinterpret the history of design. Especially we should straighten exchange and collision between culture and art in the history of design and art. According to above analysis, we can see that the vast majority of Art Nouveau artists were more or less influenced by the oriental art and other exotic cultures. Therefore, to study the oriental spirit in the new art movement and review this period of history can further deepen people understanding on design subject, design phenomenon and design culture, help us use foreign cultures and accelerate the development of our cultural art in this information age.

\section{REFERENCES}

[1] Liang Mei. Introduction to the New Art Movement, Decoration, Issue 5 in 2007.

[2] Zhou Bo: Native and Exotic Characteristics of the New Art Movement, Journal of Zhengzhou University of Light Industry (SOCIAL SCIENCE EDITION), Issue 4 in 2009.

[3] Luo Xianhui. Nature View of the New Art Movement, Art and Design (Theory), Issue 5 in 2010.

[4] Xu Jia. The New Art Movement: The Ideological Pioneers of Modernistic Design, Hundred Schools in Arts, Issue 3 in 2006.

[5] Liu Cun. The Influence of Japanese Ukiyo-e on Art Nouveau, Design Art" (Journal of Shandong College of Arts and Crafts), Issue 2 in 2008.

[6] Liang Zhi. Return to Nature: Decorative Elements of the New Art Movement, Great Masters, Issue 11 in 2010.

[7] Jiang Junchen. Oriented Enlightenment from Western New Art Movement, Hundred Schools in Arts, Issue 2 in 2012. 